\title{
NATIONAL PHARMACARE IN CANADA: 2019 OR BUST?
}

\section{Owen Adams and Jordyn Smith}

\section{SUMMARY}

It is the Canadian public policy issue that rears its head with regularity, never achieving much more than discussion, and yet never going away entirely. The issue is pharmacare, and once again it is back for discussion among academics and policy-makers, and once again it looks like the discussions will not go anywhere anytime soon. The proposal for a publicly funded pharmaceuticalcoverage plan is frequently on the table in Canada, but it still is not in the cards.

Canada is the only member country of the Organisation for Economic Cooperation and Development (OECD) with a public health-care system that does not include coverage for pharmaceuticals. As a result, Canada spends markedly less public money than the OECD average on pharmaceuticals (42 per cent of drug payments are public funds, versus the average 70 per cent), although it also spends more than the OECD average on hospitals and doctor visits. Advocates for an expansion of the publicly funded medicare system to include prescription medication note that it has become common for some lower-income Canadians who lack private drug insurance to leave prescriptions unfilled due to the cost, or will miss doses. This affordability problem for lower-income Canadians appears to be getting more serious.

However, while Canadians seem to express support for the idea of pharmacare when asked about it in surveys, it remains well behind a list of other improvements to the health-care system that they consider to be of higher priority. They are more interested in improving access and wait times, and they are more concerned about the sustainability of the current system given the increased demands of the aging population. Both employers and workers, meanwhile, also support the existing model of employer-provided drug plans.

Perhaps the biggest obstacle for champions of pharmacare, however, is that the term can mean so many different things to different people. There is virtually no consensus on what would even be the appropriate Canadian system, particularly 
in light of how significant a factor private coverage already is in Canada. A pharmacare plan might include anything from the drastic step of eliminating all private coverage and subsidizing all prescription medicine for all patients regardless of income, to a much narrower program that covers some portion of the cost of only some drugs, for some income levels. There are also countless different possible models between those two. The matter of how much each level of government, provincial/territorial or federal, would be responsible for funding drugs is a whole other, rather thorny matter.

The timing of this latest discussion about pharmacare - stimulated mainly by recent proposals and fuelled by the success of the pan-Canadian Pharmaceutical Alliance in negotiating better bulk drug prices - is also particularly unfavourable. There has been a sudden shift in the dynamic between the federal government and the provinces, where before premiers stood together and collectively bargained with the federal government for health-care funding, but recently splintered and are now making individual deals (while Quebec continues to insist that it must have complete freedom from Ottawa to design its own health system). The difficult fiscal situation across Canada, with so many governments running up debts, would also seem to make it highly unlikely that there will be much enthusiasm for embarking on a new and sizeable social program costing billions of dollars a year. Lacking enough leaders to passionately champion it, and with a public generally uninterested and very unclear on what a national pharmacare program would even entail, it seems that the current discussion about implementing a pharmacare system may come to a stall, like so many discussions before it. 


\section{SUMMARY}

Since the introduction of medicare in Canada in the 1950s and '60s for hospital and medical care, the goal of universal coverage for prescription drugs has been an elusive one. In 2014, of the estimated $\$ 29.4$ billion spent in Canada on prescription drugs (accounting for 13.6 per cent of total health spending), governments accounted for 42.6 per cent of that spending, and private insurers and out-of-pocket payment accounted for 35.2 and 22.2 per cent respectively. ${ }^{1}$ Lately, there has been a resurgence of interest in a national drug plan (following proposals by Gagnon in 2010 and Morgan and colleagues in 2015) fuelled by the success of the pan-Canadian Pharmaceutical Alliance (pCPA) in lowering prices of brand-name and generic prescription drugs for government-funded drug plans. Hence, the question is being raised again: Has the time come for national pharmacare?

This note reviews the recent developments and discusses some of the key considerations in moving forward, including: the cost, the federal/provincial-territorial dynamics, the issue of winners and losers, and the level of support from the Canadian public and key stakeholders. Based on these considerations, the answer to the question is "not yet." Hopefully, the report of the study on national pharmacare being conducted by the House of Commons standing committee on health, expected some time in 2017, will result in serious deliberation and progress toward universal access to prescription drugs in Canada.

\section{THE UNFINISHED BUSINESS OF MEDICARE}

Pharmacare is clearly part of the unfinished business of medicare. Numerous authors have pointed out that Canada is the only developed country that does not include prescription drugs as part of its universal health program. Table 1 below shows how Canada compares on the proportion of public spending for major categories of health expenditure with the 22 member countries of the Organisation for Economic Co-operation and Development (OECD) for which data were available for 2012. TABLE 1 PUBLIC SPENDING AS PER CENT OF TOTAL SPENDING: MAJOR HEALTH SPENDING CATEGORIES,
CANADA AND 22-OECD-COUNTRY AVERAGE, 2012

$\begin{array}{ccccc} & \text { \% Public Spending } & & \\ & \text { Prescription Drugs } & \text { Hospitals } & \text { Doctors' Offices } & \text { Dentists' Offices } \\ \text { Canada } & 42 & 91 & 99 & 6 \\ \text { OECD Average } & 70 & 88 & 72 & 34\end{array}$

Source: OECD.Stat, Doctors' offices figure for Sweden is 2009.

In the case of prescription medications, Canada was more than one-third (40-per-cent) below the OECD average.

As a result of prescription drugs not being included in medicare, there is wide variation today in provincial-territorial (PT) government per-capita spending on prescription drugs. Table 2 shows that, for 2014, PT government per-capita expenditure on prescription drugs ranged across the provinces from \$196 in British Columbia and \$219 in Prince Edward Island, to \$317 in Alberta and \$348 in Ontario, according to estimates from the Canadian

"Prescribed Drug Spending in Canada, 2016: A Focus on Public Drug Programs" (Canadian Institute for Health Information, 2016), https://secure.cihi.ca/free_products/Prescribed\%20Drug\%20Spending\%20in\%20Canada_2016_EN_web.pdf. 
Institute for Health Information (CIHI). ${ }^{2} \mathrm{CIHI}$ does not provide estimates of private percapita prescription drug spending (private insurance plus out-of-pocket payments) below the national level.

\section{TABLE 2 SPENDING ON PRESCRIPTION DRUGS: SELECTED INDICATORS BY PROVINCE AND TERRITORY}

\begin{tabular}{|c|c|c|c|c|}
\hline Province/ Territory & $\begin{array}{c}\text { PT govt. spending } 2014 \\
\text { (\$million) }\end{array}$ & $\begin{array}{c}\text { PT govt. spending } \\
\text { per capita, 2014 } \\
\text { (\$million) }\end{array}$ & $\begin{array}{c}\text { Private insurance, } 2014 \\
\text { (\$million) }\end{array}$ & $\begin{array}{c}\text { Average household } \\
\text { out-of-pocket, \$2015 }\end{array}$ \\
\hline NL & 142.6 & 269 & 177 & 440 \\
\hline PE & 32.0 & 219 & 32 & 456 \\
\hline NS & 266.9 & 283 & 337 & 401 \\
\hline NB & 179.9 & 238 & 284 & 544 \\
\hline QC & $2,480.8$ & 302 & 2,369 & 314 \\
\hline ON & $4,753.5$ & 348 & 4,626 & 459 \\
\hline MB & 303.8 & 237 & 249 & 491 \\
\hline SK & 322.1 & 287 & 192 & 373 \\
\hline AB & $1,308.1$ & 317 & 1,065 & 498 \\
\hline BC & 908.1 & 196 & 894 & - \\
\hline YT & 7.9 & 214 & - & - \\
\hline NT & 7.7 & 174 & - & - \\
\hline NU & 4.9 & 136 & - & - \\
\hline Territories & 20.5 & 175 & 23 & 417 \\
\hline Canada & $10,718.3$ & 302 & 10,247 & \\
\hline
\end{tabular}

a CIHI, National Health Expenditure Database 1975-2016, Table C.4.1, C.4.3,D.4.1-13.

${ }^{b}$ Canadian Life and Health Insurance Association.

c Statistics Canada, Survey of Household Spending, 2015.

Table 2 also shows the significant role of private insurance in every region of Canada. Data provided by the Canadian Life and Health Insurance Association, shown in Column 3 of Table 2, show that private health insurance companies paid out $\$ 10.2$ billion for prescription drug claims in 2014, representing 96 per cent of the $\$ 10.7$ billion paid for by PT governments. In three provinces - Newfoundland and Labrador, Nova Scotia and New Brunswick - the amount paid by private insurance exceeds that paid by governments. Table 2 also shows that there is wide variation in average household out-of-pocket spending on prescription drugs, according to Statistics Canada's Survey of Household Spending (SHS). In 2015, this ranged from a low of \$314 in Ontario to a high of \$498 in B.C. ${ }^{3}$

Significant variation is evident when looking at household out-of-pocket spending on prescription drugs by income quintile (detailed data not shown). The pattern in most provinces is that the lowest income quintile has the lowest out-of-pocket spending and the second-lowest quintile has the highest. In Quebec for example, the second-lowest quintile spent \$285 more on average than the lowest quintile (\$665 versus \$380). ${ }^{3}$ This pattern likely reflects the availability of public drug programs for those with the lowest incomes and

2 Canadian Institute for Health Information website, “National Health Expenditure Database 1975 to 2016," Table D 4.1.1D4.13.1, https://www.cihi.ca/en/spending-and-health-workforce/spending/national-health-expenditure-trends, accessed February 24, 2017.

3 Statistics Canada, CANSIM Table 203-0022, "Survey of household spending (SHS), household spending, Canada, regions and provinces, by household income quintile." 
who lack private coverage. This is supported by a Wellesley Institute analysis of Statistics Canada's 2011 Survey of Labour and Income Dynamics that showed that fewer than one in three people earning less than $\$ 20,001$ annually had employer-provided medical benefits compared with three out of four (or greater) in income groups earning more than $\$ 30,000{ }^{4}$

It is also evident that out-of-pocket prescription drug costs are a particular issue for seniors. Average out-of-pocket spending for households headed by someone 65 years old or older in 2015 (\$646) was 55-per-cent greater than the average for all households (\$417). ${ }^{5}$ Moreover, in a detailed analysis of the 2009 Survey of Household Spending, Caldbick et al. found that households headed by a senior were three times as likely as the household average to report spending three per cent of their household income on prescription drugs (22.5 versus 8.2 per cent). ${ }^{6}$

Aside from overall differences in public spending, there are also differences across provinces and territories in which medications are covered, particularly in the case of cancer drugs. The Cancer Advocacy Coalition of Canada reported in 2014 that four provinces fully fund access to cancer medications taken outside a hospital. In Ontario and Atlantic Canada, however, full provincial funding is limited to cancer drugs that must be taken in a hospital setting and are on the provincial formulary; if the drug is taken outside of hospital (oral or injectable), the patient and family may have to pay significant out-ofpocket costs. ${ }^{7}$ More generally, the Canadian Cancer Society has reported that persons moving from one province to another may find that a medication covered in their former province is not covered in the new one. ${ }^{8}$ A recent qualitative key informant study also reported significant differences in public coverage of prescription drugs for neurological conditions across jurisdictions. ${ }^{9}$

Other sources confirm that the cost of prescription medication is an issue for many Canadians. In the Commonwealth Fund's 2013 International Health Policy Survey of adults age 18 and over, eight per cent of the Canadian respondents said that they had either not filled a prescription or skipped doses because of cost issues..$^{10}$ On its 2014 survey of older adults 55 and over, seven per cent of Canadian respondents reported having done so. ${ }^{11}$ On the 2016 survey of adults age 18 and over, the percentage of Canadian respondents with a cost barrier to prescription drugs had increased to 10 per cent, and those with

4 Steve Barnes and Laura Anderson, "Low earnings, Unfilled Prescriptions: Employer-Provided Health Benefit Coverage in Canada" (Wellesley Institute, 2015), http://www.wellesleyinstitute.com/wp-content/uploads/2015/07/Low-EarningsUnfilled-Prescriptions-2015.pdf.

5 Statistics Canada, CANSIM Table 203-0026, "Survey of household spending (SHS), household spending, by age of reference person."

6 S. Caldbick et al., "The financial burden of out of pocket prescription drug expenses in Canada," International Journal of Health Economics and Management 15, 3 (2015): 329-38.

7 “2014-2015 Report Card on Cancer in Canada" (Cancer Advocacy Coalition of Canada, 2015), http://www.canceradvocacy. ca/reportcard/2014/Report\%20Card\%20on\%20Cancer\%20in\%20Canada\%202014-2015.pdf.

8 “Cancer Drug Access for Canadians" (Canadian Cancer Society, 2009), http://www.colorectal-cancer.ca/IMG/pdf/cancer_ drug_access_report_en.pdf.

9 S. Guilcher et al., "The financial burden of prescription drugs for neurological conditions in Canada: results from the National Population Health Study of Neurological Conditions," Health Policy (2017).

10 C. Schoen et al., "Access, affordability, and insurance complexity are often worse in the United States compared to ten other countries," Health Affairs 32, 12 (2013): 2205-15.

11 "How Canada compares: results from the Commonwealth Fund 2014 international health policy survey of older adults" (Canadian Institute for Health Information 2014), https://www.cihi.ca/sites/default/files/document/common_survey_ppt_en.pptx. 
below-average incomes were more than four times as likely to report a cost barrier than those with above-average incomes (17 versus four per cent). ${ }^{12}$ In addition to the results of the Commonwealth Fund surveys, a 2015 survey by the Angus Reid Institute also asked Canadians about not renewing a prescription or splitting pills due to cost, finding that almost one in four respondents (23 per cent) reported that they or someone in their household had done one or both of those things. ${ }^{13}$ Himmelstein et al. reported on a survey of Canadians who experienced bankruptcy between 2008 and 2010. They found that 74.5 per cent of the respondents who had had a medical bill within the last two years reported that prescription drugs were their biggest medical expense. ${ }^{14}$

At least two Canadian studies have documented the impact that out-of-pocket costs, lack of insurance and low income have on non-adherence ${ }^{15}$ to prescription regimens. Law et al. examined cost-related non-adherence in the 2007 Canadian Community Health Survey and found that those without drug insurance were more than four times as likely to report non-adherence than those with insurance. The predicted rate of non-adherence among those with low household incomes and no drug insurance was almost 10 times as high as that among those with high incomes and drug insurance (35.6 versus 3.6 per cent). ${ }^{16}$ Based on a large-scale study of the incidence of primary non-adherence (defined as not filling a new prescription within nine months) in a group of some 70,000 Quebec patients, Tamblyn et al. reported that there was a 63 -per-cent reduction in the odds of non-adherence among those with free medication over those with the maximum level of co-payment. They also reported that the odds of non-adherence increased with the cost of the medication prescribed. ${ }^{17}$

In summary, there is no dispute than affordability of prescription drugs is an issue for many Canadians and it appears to be a growing one.

\section{EVOLUTION OF PHARMACARE PROPOSALS}

Since 1964 a number of proposals for pharmacare have been put forward. Appendix A provides a snapshot chronology that focuses on their implications for public funding. References are given in the paper.

\section{4-1997}

In 1964, the Hall commission recommended 50/50 cost-sharing between the federal and provincial governments toward the establishment of a prescription drug program, with a $\$ 1.00$ charge for each prescription. At the time, prescription drugs represented 6.5 per cent

12 "How Canada compares: results from the Commonwealth Fund's 2016 International Health Policy Survey of Adults in 11 Countries" (Canadian Institute for Health Information 2016), https://www.cihi.ca/sites/default/files/document/ commonwealth-fund-2016-chartbook-en-web-rev.pptx.

13 "Prescription drug access and affordability an issue for nearly a quarter of all Canadian households" (Angus Reid Institute, 2015), http://angusreid.org/wp-content/uploads/2015/07/2015.07.09-Pharma.pdf.

14 D. Himmelstein et al., "Health issues and health care expenses in Canadian bankruptices and insolvencies," International Journal of Health Services 44, 1 (2014): 7-23.

15 Non-adherence can be defined as doing something to make a medication last longer or failing to fill or renew a prescription. Journal 184, 3 (2012.): 297-302.

17 R. Tamblyn et al., "The incidence and determinants of primary nonadherence with prescribed medication in primary care," Annals of Internal Medicine 160 (2014): 441-50. 
of spending on personal health services. ${ }^{18}$ This recommendation was not implemented. Indeed, the federal and provincial health ministers appointed a committee on the costs of health services in February 1969, just seven months after medicare came into effect, and only two provinces had enrolled. ${ }^{19}$ In its November 1969 report, the committee highlighted that the cost of health services had more than doubled between 1957 and 1967 to reach $\$ 3.7$ billion and might reach $\$ 6.2$ billion by $1972 .{ }^{19}$ The Hall report also contained 25 forwardlooking recommendations on pharmaceuticals that remain current to this day, including bulk purchasing, generic substitution and a national formulary. ${ }^{18}$

Subsequently, a proposal for a drug-price program was developed in 1971-72, which Boothe has documented in her recent monograph on the development of national pharmaceutical insurance in Australia and the United Kingdom, and the lack of it in Canada. ${ }^{20}$

The next concerted discussion on a national program for prescription drugs (pharmacare) did not occur until the National Forum on Health (NFH), which was struck in 1994 and reported in 1997. A working-group paper on pharmaceutical policy recommended first-dollar coverage for prescription drugs, but acknowledged that, if that could not occur overnight, "over time we propose to shift private funding on prescribed pharmaceuticals (estimated at $\$ 3.6$ billion in 1994) to public funding." 21 The NFH included this recommendation in its final report, noting that "the absorption of currently operating plans by a public system may involve transfer of funding sources as well as administrative apparatus." ${ }^{22}$ Such a significant shift is not without precedent. A study prepared for the Hall commission estimated that 9.6-million Canadians, representing 53 per cent of the total population, had some form of not-for-profit or commercial insurance coverage for medical and/or surgical services in 1961. ${ }^{23}$ These plans were all displaced as the provinces joined medicare.

It is instructive to place the 1994 prescription drug expenditure cited by the NFH in today's context. According to the Bank of Canada's inflation calculator, \$6.5 billion in costs in 1994 would be $\$ 9.29$ billion in costs in $2014 .^{24}$ The Canadian Institute for Health Information (CIHI) estimates that actual spending in 2014 was $\$ 29.4$ billion $^{25}$ - 216-per-cent above the level of 1994 spending (in 2014 dollars), compared to population growth of 23 per cent over the same time period. ${ }^{26}$ Annual prescription drug spending increases averaged 7.7 per cent over the period, although they have averaged just 1.6 per cent since $2010 .{ }^{27}$

18 Royal Commission on Health Services Report, Volume One (Ottawa: Queen's Printer, 1964).

19 J. Munro, “Task force reports on the cost of health services in Canada. Volume 1 Summary” (Ottawa: Queen's Printer for Canada, 1970).

20 K. Boothe, Ideas and the Pace of Change: National Pharmaceutical Insurance in Canada, Australia and the United Kingdom (Toronto: University of Toronto Press, 2015).

21 "Directions for a Pharmaceutical Policy in Canada" (National Forum on Health), http://www.hc-sc.gc.ca/hcs-sss/pubs/ renewal-renouv/1997-nfoh-fnss-v2/index-eng.php.

22 “Canada Health Action: Building on the Legacy" (National Forum on Health, 1997).

23 C. Berry, Voluntary Medical Insurance and Prepayment (Ottawa: Queen's Printer, 1965).

24 Bank of Canada website, Inflation calculator, http://www.bankofcanada.ca/rates/related/inflation-calculator/?page_moved=1.

25 CIHI, "Prescribed drug."

26 Statistics Canada, Table 051-0001, "Estimates of population, by age group and sex for July 1, Canada, provinces and territories."

27 CIHI website, "National," Table A.3.3.1, https://www.cihi.ca/en/spending-and-health-workforce/spending/national-healthexpenditure-trends. 
A costing study for a pharmacare plan was put forward by Palmer D'Angelo Consulting Inc. in September 1997. They estimated that a fully public pharmacare plan would require increased public funding of $\$ 4.3$ billion. $^{28}$

\section{7-2012}

Following the NFH report, in the 1997 speech from the throne, the government committed to "develop a national plan, timetable and a fiscal framework for providing Canadians with better access to medically necessary drugs," but nothing further was made public. ${ }^{29}$ Of note, Quebec launched its universal drug plan in 1997, which included a mandate for all residents to have either private or public coverage.

In 1999, all first ministers except Quebec's then premier, Lucien Bouchard, signed the Social Union Framework Agreement (SUFA). While it would seem that SUFA has been relegated to history, it is significant for having established principles to guide any future federal cost-shared program offerings in the health arena. SUFA included requirements for consultation and effectively provided for compensation for provinces and territories providing existing programs in areas where the federal government might wish to engage. ${ }^{30}$

In January 2000, then federal health minister Allan Rock wrote to his provincial counterparts to propose that they meet in May to discuss primary care, home and community care and accountability to Canadians through information about health outcomes. ${ }^{31}$ That provoked an immediate, hostile reaction from the provincial health ministers. ${ }^{32}$ This was noteworthy for two reasons. First there was no mention of pharmacare; second, this was a prelude to the first of three First Ministers' Health Accords in September 2000.

Pharmacare was subsequently examined in two national studies, both of which recommended federal involvement in reimbursing "catastrophic" prescription drug expenditures that exceeded certain thresholds relative to household income. The Senate study on the state of the health-care system in Canada, chaired by Michael Kirby, was authorized in March 2001 and the Commission on the Future of Health Care in Canada, headed by Roy Romanow, was approved in April 2001. Both issued their final reports in 2002.

The Kirby plan was designed so as to avoid the necessity of eliminating existing private plans or the provincial/territorial public plans, not unlike the approach taken by Quebec in 1997. In the Kirby plan, in the case of public plans, personal prescription drug expenses for any family would be capped at three per cent of total family income. The federal government would then pay 90 per cent of prescription drug expenses in excess of $\$ 5,000$. In the case of private plans, sponsors would have to agree to limit out-of-pocket costs

28 Palmer D'Angelo Consulting Inc. National pharmacare cost impact study. Ottawa, 1997. www.pdci.ca/publications/ Pharmacare\%20Impact\%20Study\%20Final\%20Report.pdf.

29 Speech from the throne to open the first session 36th Parliament of Canada, http://www.pco-bcp.gc.ca/index. asp?lang=eng\&page=information\&sub=publications\&doc=aarchives/sft-ddt/1997-eng.htm.

30 "A Framework to Improve the Social Union For Canadians" (Canadian Intergovernmental Conference Secretariat, 1999), http://www.scics.ca/en/product-produit/agreement-a-framework-to-improve-the-social-union-for-canadians/.

31 A. Rock, Unpublished letter to provincial-territorial health ministers (January 2000).

32 A. Milroy, "Scorn greets Rock's health plan," The Globe and Mail, January 28, 2000, A1. 
to $\$ 1,500$ per year, or three per cent of family incomes, whichever was less. The federal government would then agree to pay 90 per cent of drug costs in excess of $\$ 5,000$ per year. Both public and private plans would be responsible for the difference between out-of-pocket costs and $\$ 5,000$, and private plans would be encouraged to pool their risk. Kirby estimated that this plan would cost approximately $\$ 500$ million per year. ${ }^{33}$

The Romanow commission recommended a \$1-billion catastrophic drug transfer, through which the federal government would reimburse 50 per cent of the costs of provincial and territorial drug insurance plans above a threshold of $\$ 1,500$ per person per year. ${ }^{34}$

Also in 2002 Palmer D'Angelo updated their 1997 study. Their estimate ${ }^{35}$ of the increased public funding for a fully public program had increased to $\$ 8.1$ billion. Following the Kirby and Romanow reports, there was a back-and-forth exchange between the federal and provincial-territorial governments on a plan for catastrophic coverage. In their February 2003 accord, first ministers agreed to ensure that Canadians would have reasonable access to catastrophic drug coverage by March 2006. ${ }^{36}$ Pharmacare was a campaign issue in the federal election held in June 2004. The federal Liberals pledged to work with the PT governments to "develop and help fund" a national pharmaceutical plan. ${ }^{37}$ The Conservative party committed to implementing the 2003 accord, including a proposal "that the federal government assume direct responsibility for the catastrophic plan in the Accord." 38 At their annual summer meeting a month later, the premiers called on the federal government to "assume full financial responsibility for a comprehensive drug program for all Canadians," with compensation to Quebec for its existing drug program. ${ }^{39}$ In the September 2004 health accord, first ministers directed health ministers to develop a nine-point "national pharmaceuticals strategy" (NPS), including costing options for catastrophic coverage. ${ }^{40}$ The 2004 accord was also noteworthy for explicitly recognizing "asymmetrical federalism," acknowledging a greater autonomy for Quebec than for other provinces. This document indicated that while Quebec supported the objectives and principles set out in the accord, it would develop its own plans for reducing wait times, managing health-care human resources, strategies for drug access, and other elements. ${ }^{41}$

A federal-provincial-territorial ministerial task force on the NPS was struck and a progress report was issued in June 2006. This report proposed four options for catastrophic

33 The Health of Canadians - The Federal Role. Volume Six: Recommendations for Reform (Standing Senate Committee on Social Affairs, Science and Technology, 2002).

34 Building on Values: The Future of Health Care in Canada (Commission on the Future of Health Care in Canada, 2002).

35 Palmer D'Angelo Consulting Inc. Cost impact study for a national pharmacare program for Canada. September, 2002. www.pdci.ca/publications/National_Pharmacare_2002-Full_Report.pdf.

36 First Ministers' Accord on Health Care Renewal (Canadian Intergovernmental Conference Secretariat, 2003), http://www.scics.gc.ca/CMFiles/800039004_e1GTC-352011-6102.pdf.

37 "Health care: a fix for a generation — costing the plan" (Liberal Party of Canada, 2004).

38 "Demanding better" (Conservative Party of Canada, 2004).

39 "Premiers' action plan for better health care: resolving issues in the spirit of true federalism," communiqué (Council of the Federation, July 30, 2004), http://canadaspremiers.ca/phocadownload/newsroom-2004/healtheng.pdf.

40 "A 10-year plan to strengthen health care” (Canadian Intergovernmental Conference Centre, ), http://www.scics.gc.ca/ CMFiles/800042005_e1JXB-342011-6611.pdf.

41 “Asymetrical federalism that respects Quebec's jurisdiction" (Canadian Intergovernmental Conference Secretariat, 2004), http://www.scics.ca/wp-content/uploads/CMFiles/800042012_e1JWF-342011-9468.pdf. 
coverage, with estimates for new public funding ranging from $\$ 1.4$ to $\$ 4.7$ billion. ${ }^{42}$ Two stakeholder consultations were held with employers/insurers ${ }^{43}$ and health-professional associations $^{44}$ in 2007, but nothing was heard publicly thereafter. At their September 2008 meeting, the PT health ministers called for a national standard for drug coverage not to exceed five per cent of the provincial net income base, and for the federal government to share 50/50 in the estimated \$5.03-billion cost. ${ }^{45}$ In its campaign platform for the October 2008 election, the Liberal party pledged $\$ 900$ million to work with the PT governments to establish a national minimum level of catastrophic coverage for which those jurisdictions meeting the level would be eligible for compensation. ${ }^{46}$ In January 2009, the Health Council of Canada described the situation of the NPS as being at an "impasse" and urged federal, provincial and territorial governments to come to the table to resolve the issues, noting that without such collaboration the NPS "will remain largely a prescription unfilled." ${ }^{47}$

In the 2012 final parliamentary review of the 2004 health accord, the Senate committee on social affairs, science and technology heard concerns from witnesses about the lack of progress on a national standard for catastrophic coverage, and one of its recommendations (No. 28) called on the federal government to work with the PT governments to develop a "national pharmacare program based on the principles of universal and equitable access for all Canadians." ${ }^{48}$ In its response, the federal government stated that the NPS work had stimulated individual provinces and territories to adopt catastrophic drug plans. ${ }^{49}$ In 2012 , the federal government announced its intention to develop a framework to increase access to orphan drugs for rare disease ${ }^{50}$ and in 2014 announced the launch of a pilot project for patient involvement to inform future reviews of orphan drugs. ${ }^{51}$

\section{The Gagnon (2010) and Morgan (2015) Proposals}

Since 2010, two proposals have sparked considerable interest in the prospect of a pharmacare program that would be offered on the same terms and conditions as medicare (principally single-public-payer coverage with either minimal or no co-payment). The

42 "National Pharmaceuticals Strategy progress report" (National Pharmaceuticals Strategy, 2006), http://www.hc-sc.gc.ca/ hcs-sss/alt_formats/hpb-dgps/pdf/pubs/2006-nps-snpp/2006-nps-snpp-eng.pdf.

43

"Report to National Pharmaceuticals Strategy," Catastrophic Drug Coverage Working Group: Insurers and employers stakeholder-engagement session, meeting summary (Victoria, B.C., September 17, 2007).

44

"Report to National Pharmaceuticals Strategy," Catastrophic Drug Coverage Working Group: Health-care professional associations stakeholder-engagement session, meeting summary (Victoria, B.C, October 2, 2007).

45

"Backgrounder: National Pharmaceutical Strategy Decision Points" (Canadian Intergovernmental Conference Secretariat), http://www.scics.ca/en/product-produit/backgrounder-national-pharmaceutical-strategy-decision-points/.

46 "Stéphane Dion announces new drug plan,” Liberal Party of Canada press release, September 16, 2008.

47 "A Commentary on the National Pharmaceutical Strategy: A Prescription Unfilled" (Health Council of Canada, 2009), http://www.healthcouncilcanada.ca/tree/2.35.1-HCC_NPS_Commentary_WEB.pdf.

48 "Time for Transformative Change: A Review of the 2004 Health Accord" (Standing Senate Committee on Social Affairs, Science and Technology, 2012), http://www.parl.gc.ca/content/sen/committee/411/soci/rep/rep07mar12-e.pdf.

49 Government of Canada, "Taking Action to Improve the Health of Canadians," http://www.parl.gc.ca/Content/SEN/ Committee/411/soci/rep/rep07GovResponse-e.pdf.

50 Health Canada, "Harper government takes action to help Canadians with rare diseases," news release, October 3, 2012, http://www.prnewswire.com/news-releases/harper-government-takes-action-to-help-canadians-with-rarediseases-172494101.html.

51 Government of Canada, "Minister Ambrose announces patient involvement pilot for orphan drugs," news release, August 6, 2014, http://news.gc.ca/web/article-en.do?nid=873619. 
first was by Marc-André Gagnon in 2010, published for the Canadian Centre for Policy Alternatives. The proposal was developed on the basis of a review of cross-provincial and international practices in pharmaceutical policy. The review formed the basis of a set of 11 assumptions that were used to develop four scenarios that resulted in estimates of prescription drug cost savings over the 2008 baseline expenditure of $\$ 25.1$ billion, ranging from $\$ 2.9$ billion to $\$ 10.7$ billion. ${ }^{52}$ The scenario with the greatest savings was based on adoption of New Zealand's drug-purchasing policies ${ }^{53}$ and the results of the 11 parameters for this scenario are shown below.

TABLE 4.4 Scenario 4: Universal pharmacare with cancellation
of the industrial policies associated to drug costs
Current expenditure on prescription drugs
Distribution of prescription drug costs/benefits
Savings from competitive purchasing
Growth in expenditures from increase in use
Reduction in expenditures from decrease in dispensing fees
Elimination of the monthly deductible in Quebec
Elimination of the 15-year rule in Quebec
Total savings on prescription drugs
Total prescription drug costs with a universal pharmacare plan
Additional impacts other than for prescription drugs

In a 2014 update published by the Canadian Federation of Nurses Unions, Gagnon estimated that a first-dollar coverage program would save 10 to 41 per cent of prescription drug costs, representing savings of as much as \$11.4 billion annually on a 2012-13 base of $\$ 27.7$ billion. $^{54}$

Steve Morgan and colleagues have estimated that a universal public plan with small copayments could reduce prescription drug spending by $\$ 7.3$ billion on a base of $\$ 22.3$ total spending in 2012-13.. ${ }^{55}$ The key modelling parameters for their base scenario and their associated savings are as follows:

- A change in generic prices of $-\$ 2.5$ billion assumes that Canadian prices for generic drugs will fall to a level equal to moderately performing comparators, such as the U.K. and Sweden;

\footnotetext{
52 M. Gagnon, "The Economic Case for Universal Pharmacare" (Canadian Centre for Policy Alternatives, 2010), https://s3.amazonaws.com/policyalternatives.ca/sites/default/files/uploads/publications/National\%20Office/2010/09/ Universal_Pharmacare.pdf.

53 See: Pharmaceutical Management Agency, “Introduction to PHARMAC,” http://www.pharmac.govt. nz/2011/09/16/01INTRO.pdf.

54 M. Gagnon, "A roadmap to a rational pharmacare policy in Canada" (Ottawa: Canadian Federation of Nurses Unions, 2014).

55 S. Morgan et al., "Estimated cost of universal public coverage of prescription drugs in Canada," Canadian Medical Association Journal 187, 7 (2015): 491-497.
} 
- A change in brand-name prices of $-\$ 2.5$ billion assumes Canadian prices fall to a level equal to the U.K., where patented drug prices are 23-per-cent lower than in Canada;

- A change in product selections within drug classes of $-\$ 2.7$ billion assumes that offpatent drugs are prescribed at the third-highest rate among provincial drug plans in Canada, and the same for generic prescribing rates;

- Increases in utilization of three per cent and \$680 million in public spending; and

- Changes in co-payments assumes $\$ 2.00$ for generics and $\$ 10.00$ for brand-name drugs. ${ }^{56}$

The Morgan et al. paper has been accessed more than 28,000 times from March 2015 through October 2016. ${ }^{57}$ In both the Gagnon and Morgan proposals, the majority of the savings are achieved through lower prices for generic and brand-name drugs. Both studies documented their modelling assumptions in detail and developed a range of estimates.

On June 3, 2015 the Liberal Senate Forum held an open caucus session on pharmacare ${ }^{58}$ and on June 8, 2015, Ontario Health Minister Eric Hoskins — in follow-up to his Dec. 15, 2014 declaration that "the time for national pharmacare has come" 59 — hosted his counterparts from seven other jurisdictions at a roundtable meeting that heard from Gagnon and Morgan and other academics and experts about the prospects for pan-Canadian pharmacare. ${ }^{60}$ The roundtable report identified eight areas of broad consensus, including acknowledgement of a gap in coverage and the potential for savings, as well as the need to improve the quality of prescribing. The report also identified five key issues to resolve, including first-dollar coverage, the reaction from the public and employers, and the question of whether federal government participation is necessary. ${ }^{61}$

In July 2015, just prior to the annual meeting of premiers, Morgan and colleagues released Pharmacare 2020, which set out five recommendations calling for the establishment of pharmacare as a single-payer system with a publicly accountable management agency, to be fully implemented by $2020 .^{62}$ The Pharmacare 2020 website presently lists almost 300 endorsements. In the communiqué following their meeting, the premiers emphasized the importance of the pCPA and noted the prospect of the participation of the federal government, and also indicated that the PTs would examine pharmacare programs in other countries. ${ }^{63}$

In September 2015, there were three proposals for an approach to universal pharmacare that involved the continued participation of private plans. As part of its Pharmacare 2.0

\footnotetext{
56 See S. Morgan et al., "Estimated," Appendix 1: Technical details concerning cost modelling and Appendix 2: Sensitivity testing.

57 Canadian Medical Association Journal, unpublished tabulation.

58 Liberal Senate Forum, Open Caucus June 3, 2015 — Pharmacare, http://liberalsenateforum.ca/open-caucus/june-3-2015-pharmacare/.

63 The Council of the Federation, "Health care remains a top priority," news release, July 17, 2015,

http://www.pmprovincesterritoires.ca/phocadownload/newsroom-2015/health_care-final.pdf.
} 
initiative, the Canadian Pharmacists Association ( $\mathrm{CPhA}$ ) released a discussion paper that set out three principles and associated priorities toward achieving universal coverage. Under the principle "innovation and sustainability," the CPhA proposed that a pan-Canadian pharmacare framework should be built on co-operation between public and private plans and should include means-tested patient contributions. ${ }^{64}$ As part of its 2015 federal election call for a national seniors strategy, the Canadian Medical Association released a report commissioned from the Conference Board of Canada that included a costing of the proposal put forward in the 2002 Kirby report. Using Statistics Canada's Survey of Household Spending as the basis for its modelling, the Conference Board estimated that it would cost the federal government \$1.6 billion in 2016 to cover prescription drug spending in excess of the lesser of amount of three per cent or $\$ 1,500$ of annual household income. ${ }^{65}$ Blomqvist and Busby proposed something similar to Kirby: a "nationwide network of geared-toincome (catastrophic) plans" whereby the federal government would transfer funds to provinces whose programs respect minimal conditions for an income-tested upper limit on household drug spending. ${ }^{66}$

\section{The 2015 Federal Election and Since}

In the campaign leading up to the Oct. 19, 2015 federal election, three parties addressed prescription drug access:

- The Green party pledged to implement a national pharmacare plan that would save \$11 billion per year through bulk purchasing and also to apply a "gold standard" for pharmaceutical review to reject drugs that "hurt more people than they heal", 67

- The New Democratic Party pledged to work with the PTs to develop public, universal drug coverage through bulk purchasing and price negotiations and also to streamline the drug review and listing process; ${ }^{68}$ and

- The Liberal party pledged to join the pCPA, to address over-prescribing and adverse drug effects, and to review the Patented Medicines Prices Review Board (PMPRB) ${ }^{69}$

Following the Liberal government's election, the mandate letters of the new ministers were made public. Health Minister Jane Philpott's contained the following with respect to prescription drugs as part of a new health accord:

"It should ... improve access to necessary prescription medications. This will include joining with provincial and territorial governments to buy drugs in bulk, reducing the

\footnotetext{
64 "Principles \& Priorities: Pharmacare 2.0," Canadian Pharmacists Association discussion paper, https://www.pharmacists.ca/ cpha-ca/assets/File/cpha-on-the-issues/Pharmacare\%20Principles\%20and\%20Priorities\%20Discussion\%20Paper.pdf.

"Federal Policy Action to Support the Health Care Needs of Canada's Aging Population" (Conference Board of Canada, 2015), https://www.cma.ca/Assets/assets-library/document/en/advocacy/conference-board-rep-sept-2015-embargo-en.pdf.

66 A. Blomqvist and C. Busby, "Feasible Pharmacare in the Federation: A Proposal to Break the Gridlock" (C.D. Howe Institute, 2015), https://www.cdhowe.org/sites/default/files/attachments/research_papers/mixed/e-brief_217_0.pdf..

67

"Building a Canada that works. Together," Green Party of Canada campaign platform 2015, https://www.greenparty.ca/sites/ default/files/platform_english_web.pdf.

68 New Democratic Party of Canada. "Building the country of our dreams: Tom Mulcair's plan to bring change to Ottawa," New Democratic Party of Canada campaign platform 2015, http://xfer.ndp.ca/2015/2015-Full-Platform-EN.pdf.

69 “Investing in health and home care," Liberal Party of Canada campaign pamphlet 2015, https://www.liberal.ca/files/2015/10/ Investing-in-health-and-home-care.pdf.
} 
cost Canadian governments pay for these drugs, making them more affordable for Canadians, and exploring the need for a national formulary." ${ }^{\prime 70}$

The federal government drug programs are now participating in the pCPA. In speeches since the election, Philpott has indicated that she hopes to explore how to extend the pCPA to private insurance plans and that she is pursuing a common drug formulary for publicly funded drug plans. ${ }^{71}$ The PMPRB issued a discussion paper on the modernization of its guidelines in June 2016 to launch a review. ${ }^{72}$ In a January 2017 interview, Philpott commented on the seven comparator countries against which PMPRB sets prices. She noted that the group includes two countries with the highest prices, the U.S. and Germany, and suggested that countries with lower prices, such as Australia and New Zealand, be included instead. When pressed on the issue of a national pharmacare program, she emphasized that Canada has the second highest per-capita prescription drug prices and said that it would be irresponsible to lock in to them. ${ }^{73}$

The pCPA has had some success. It reported that, as of April 2016, joint negotiations on brand name drugs and price reductions on generic drugs have resulted in estimate annual savings of $\$ 712$ million. As of Dec. 31, 2016, it was reported that negotiations had been completed for 129 brand name drugs and that 43 more were underway. ${ }^{74}$

There seems little doubt that the sustained efforts by Gagnon, Morgan and colleagues were influential in the decision by the House of Commons standing committee on health (HESA) to adopt "a study on the development of a national Pharmacare program as an insured service for Canadians" on March 7, 2016. ${ }^{75}$ Morgan, Gagnon and Dr. Danielle Martin were in fact among the first to appear before HESA, after government agencies such as the Canadian Agency for Drugs and Technologies in Health, PMPRB and CIHI. Martin articulated five recommendations for a plan: $^{76}$

- A public plan that covers every Canadian;

- An "evidence-based" and "transparent" process that operates at "arm's length" from government and industry to decide which drugs are covered;

- Zero or very low co-payments;

- Bulk purchasing by the government in order to lower drug prices;

- A plan that encourages optimal prescribing and improves drug "quality and safety."

70 Canada. Office of the Prime Minister, minister of health mandate letter, http://pm.gc.ca/eng/minister-health-mandate-letter.

71

Remarks from the Hon. Jane Philpott, minister of health, to the Canada 2020 health summit, September 29, 2016, http://news.gc.ca/web/article-en.do?nid=1134769.

72

"PMPRB guidelines modernization discussion paper" (Patented Medicine Prices Review Board, 2016), http://www.pmprb-cepmb.gc.ca/CMFiles/Consultations/DiscussionPaper/PMPRB_DiscussionPaper_June2016_E.pdf.

73 Interview with Minister of Health Jane Philpott, The Fifth Estate, January 13, 2017, http://www.cbc.ca/fifth/blog/fullinterview-with-minister-of-health-jane-philpott.

74 Council of the Federation website, “The Pan-Canadian Pharmaceutical Alliance,” http://www.pmprovincesterritoires.ca/en/ initiatives/358-pan-canadian-pharmaceutical-alliance, accessed 02/03/17.

75 House of Commons Standing Committee on Health, minutes of proceedings, March 7, 2016, http://www.parl.gc.ca/ HousePublications $/$ Publication. asp $x$ ?Language $=\mathrm{e} \&$ Mode $=1 \&$ Parl $=42 \& S e s=1 \&$ DocId $=814258$.

76 House of Commons Standing Committee on Health, evidence, April 18, 2016, http://www.parl.gc.ca/content/hoc/ Committee/421/HESA/Evidence/EV8197723/HESAEV07-E.PDF. 
From April 2016 to Feb. 2, 2017, HESA heard from numerous other witnesses (82 in total) and received 26 briefs from various stakeholders. A profile of the participants is found in Appendix B. Taken together, the briefs and testimonies addressed many questions at the heart of the pharmacare debate. It is notable that, as of Feb. 2, 2017, there has been no representation to HESA from the pCPA or provincial drug plans. In addition, the closest thing there has been to a representation from employers was one from the Surrey Board of Trade.

There has been widespread agreement among witnesses that Canada's current patchwork of drug plans has resulted in an important coverage gap. Most participants highlighted that Canada is the only OECD country with a public health-care system that excludes pharmaceutical coverage. Many also mentioned that 10 per cent of Canadians report not adhering to a prescription because of its cost. Most participants - including government agencies, patient and health professional groups - agreed that a national pharmaceutical program of some sort should be implemented in Canada. Labour and trade organizations advocated for a national program to replace employer-sponsored drug plans, as many employers who cannot sustain rising drug prices have begun shifting costs to workers. ${ }^{77,78}$ Relieving the burden of financing prescriptions, they argued, would allow employers to provide other health benefits.

A few stakeholders, however, did not support a national public program. For instance, Dr. Ake Blomqvist, appearing on behalf of the C.D. Howe Institute, stated that "we do not think that an attempt to create a universal single-payer public plan would be helpful at this stage." 79 Speaking on behalf of the Canadian Life and Health Insurance Association (CLHIA), its president, Frank Swedlove, suggested that "the best solution for Canadians will be the one that leverages the strengths of both the public and private sectors and brings them together in a co-ordinated way." 80

The creation of an evidence-based national drug formulary, developed and maintained by an expert panel at arm's length from government and industry, was very widely supported. It was argued that such a formulary, along with an online database containing information about the drug-approval process, best practice for pharmaceuticals, and post-market research, would promote coverage consistency across Canada, improve cost-efficiency through generic and bulk purchasing and increase drug safety and optimal prescribing. Some patients and researchers, however, identified challenges: The formulary would have to be kept current; provide enough variety to meet the unique needs of patients; be designed with attention to how individuals of different sexes, genders, races, ethnicities and socioeconomic and indigenous statuses access and use drugs; and would include drugs for rare diseases, all without compromising research and development.

77 Submission from the Canadian Labour Congress to the Standing Committee on Health regarding the development of a national pharmacare program (2016), http://www.parl.gc.ca/Content/HOC/Committee/421/HESA/Brief/BR8604329/brexternal/CanadianLabourCongress-e.pdf.

"Development of a National Pharmacare Plan" (Canadian Union of Public Employees, 2016), http://www.parl.gc.ca/Content/ HOC/Committee/421/HESA/Brief/BR8449063/br-external/CanadianUnionOfPublicEmployees-e.pdf.

79

House of Commons Standing Committee on Health, evidence, September 27, 2016, http://www.parl.gc.ca/content/hoc/ Committee/421/HESA/Evidence/EV8442679/HESAEV20-E.PDF.

80

House of Commons Standing Committee on Health, evidence, May 9, 2016, http://www.parl.gc.ca/content/hoc/ Committee/421/HESA/Evidence/EV8251913/HESAEV10-E.PDF. 
First-dollar coverage was often recommended; witnesses cited evidence that even small co-payments are barriers to coverage. ${ }^{81}$ There was also significant support across briefs for a pharmacare program that is similar to or integrated into medicare. For instance, the Health Charities Coalition of Canada recommended that provinces and territories "receive increased transfer payments to implement comprehensive, evidence-based, pan-Canadian pharmacare standards." 82

On Sept. 27, 2016, HESA decided to request that the Parliamentary Budget Office (PBO) estimate the cost of implementing national pharmacare.$^{83}$ The parameters of the proposed study are outlined in Appendix C. On Dec. 13, 2016, the PBO informed HESA that the study would "require two full-time analysts over an expected six-month period and that the total cost of data from various sources will exceed $\$ 100,000 . "{ }^{44}$ The terms of reference proposed for the study are not yet public, but the HESA minutes of Dec. 13th indicate that the PBO was asked to proceed with the study with the addition of the impact of exemptions from co-payments indicated in the British National Health Service (e.g., pregnant women). ${ }^{85}$ On Dec. 22, 2016, the PBO wrote to the deputy minister of Health Canada to inquire if the department was already in possession of some of the data needed for its study, and the department replied on Jan. 13, 2017, indicating that the information requested was enclosed. ${ }^{86,87}$

In December 2016, HESA heard from the chair of the Citizens' Reference Panel on Pharmacare in Canada. Convened with a research grant from the Canadian Institutes of Health Research and other partners, Steve Morgan and colleagues assembled a group of 35 randomly selected citizens from across Canada to come together to hear from many stakeholders and experts, and develop a set of suggestions for pharmacare. Having established a basis of principles that pharmacare should be "universal, evidence-based, patient-centered, sustainable and accountable," the panel recommended:

- A pharmacare program that covers all Canadians;

- An evidence-based, patient-centered national formulary that increases drug safety while providing enough variety to meet unique patient needs and rare diseases;

- A publicly funded plan with drugs purchased in bulk to decrease prices;

- Private insurance that can be purchased, but covers only drugs outside the national formulary;

81 M. Robertson, "Understanding the Gaps in Drug Coverage in Canada's Health Care System," policy brief (2016), http://www.parl.gc.ca/Content/HOC/Committee/421/HESA/Brief/BR8614898/br-external/RobertsonMaryLou-e.pdf.

82 "Brief to the House of Commons Standing Committee on Health: Development of a National Pharmacare Program" (Health Charities Coalition of Canada, 2016), http://www.parl.gc.ca/Content/HOC/Committee/421/HESA/Brief/BR8290876/brexternal/HealthCharitiesCoalitionOfCanada-e.pdf.

83

House of Commons Standing Committee on Health, minutes of proceedings, September 27, 2016, http://www.parl.gc.ca/ HousePublications $/$ Publication .asp $x$ ? Language $=\mathrm{e} \&$ Mode $=1 \&$ Parl $=42 \&$ Ses $=1 \&$ DocId $=8444783$.

84

House of Commons Standing Committee on Health, evidence, December 13, 2016, http://www.parl.gc.ca/ HousePublications $/$ Publication. asp $x$ ?Language $=\mathrm{e} \&$ Mode $=1 \&$ Parl $=42 \&$ Ses $=1 \&$ DocId $=8701248$.

85 House of Commons Standing Committee on Health, minutes of proceedings, December 13, 2016, http://www.parl.gc.ca/ HousePublications/Publication. aspx?Language $=\mathrm{e} \&$ Mode $=1 \&$ Parl $=42 \&$ Ses $=1 \&$ DocId $=8708149$.

86 Letter to Mr. Simon Kennedy (Office of the Parliamentary Budget Office, December 22, 2016), http://www.pbo-dpb.gc.ca/ web/default/files/Documents/Info\%20Requests/2016/IR0273_HC_Estimates_National_Pharmacare_Program_EN.pdf.

87 S. Kennedy, Letter to Jean-Denis Fréchette (January 13, 2017), http://www.pbo-dpb.gc.ca/web/default/files/Documents/ Info\%20Requests/2017/IR0273_2017_01_13_Estimates_National_Pharmacare_EN.pdf. 
- Equal access to medications across the country;

- Immediate action by the government to fund a minimal list of drugs; and

- Development of a strategy to address orphan drugs for rare diseases. ${ }^{88}$

The briefs and testimony provided to HESA to date have outlined numerous perspectives on how a national pharmacare program should be designed and they advocate for the implementation of such a program. Many organizations and patient groups also provided recommendations specific to the communities they serve. It seems likely that the pharmacare study will not be completed until after the committee receives the PBO report later this year.

\section{CONSIDERATIONS IN MOVING FORWARD}

The recent concerted attention raises the question: Has the time finally come in Canada for a single-public-payer national pharmacare program? The foregoing would suggest that there are four main issues or questions that need to be addressed/resolved:

- What would be the incremental cost to the public purse of adopting a single-payer national pharmacare program?

- What are the prospects of federal-provincial/territorial collaboration in moving toward such a program?

- Who would be the winners and losers if such a program were implemented?

- What is the state of public and employer opinion toward national pharmacare?

Incremental cost: The most recent proposals provide a range of estimates depending on whether the program implemented is a full public program or a catastrophic program designed to close the gap for uninsured or underinsured people.

Gagnon's 2014 estimate (with revised industrial policies) based on 2012-13 figures is that total prescription drug costs in a pharmacare program would be $\$ 18.8$ billion. This is about $\$ 6.8$-billion greater than the 2012 level of $\$ 12.0$ billion in public funding ${ }^{89}$ (fiscal year data not available). Gagnon notes that there would be additional savings of $\$ 2.5$ billion from the elimination of administrative costs in private plans and the elimination of tax subsidies. ${ }^{52,90}$ Morgan et al.'s base scenario estimates that for 2012-13 there would be an increase in public funding of $\$ 958$ million, and that this would range from an increase of $\$ 5.4$ billion if all model parameters were set to the worst-case values, to a decrease in public funding of $\$ 2.9$ billion if they were set to best-case values. ${ }^{91}$ A 2016 study carried out by PDCI Market Access Inc. for the Canadian Pharmacists Association that did not model estimates of potential savings, estimated that on a base of $\$ 11.3$ billion of 2015 public expenditures, a public program with no co-payment would increase public spending by $\$ 16$ billion..$^{92}$

\footnotetext{
88 "Necessary Medicines: Recommendations of the Citizens' Reference Panel on Pharmacare in Canada" (Citizens' Reference Panel on Pharmacare in Canada, 2016), http://www.crppc-gccamp.ca/s/CRPPC-Final-Report.pdf. 
PDCI also provided estimates of a public-private model along the lines of the Quebec drug program. This would result in increased public spending of $\$ 2.1$ billion, which is in the range of the Conference Board estimate of \$1.6 billion for a federally funded catastrophic program using a three-per-cent household-income threshold. ${ }^{93}$

Most recently, Morgan et al. modelled the cost of introducing universal public coverage of 117 essential medicines that accounted for 44 per cent of all prescriptions and 36 per cent of total prescription drug expenditures in 2015 in Canada. They developed three scenarios based on variations in changes in utilization and the prices of brand name and generic essential medicines. In their base case, they estimated that public spending would increase by $\$ 1.2$ billion on a 2015 base of $\$ 10.8$ billion, and private spending would decrease by $\$ 4.3$ billion on a 2015 base of $\$ 15.4$ billion; there would be a total reduction of $\$ 3.0$ billion in prescription drug spending on a base of $\$ 26.2$ in total spending. ${ }^{94}$

The study that the PBO has been asked to do (Appendix C) is very comprehensive and will surely inform the discussion and debate further.

\section{Prospect of FPT Collaboration on Pharmacare}

At the present time, fiscal prospects suggest that the likelihood of either a full federal pharmacare program, or one in partnership with the provinces/territories, appears slim. The only funding pledge for health in the 2015 Liberal election platform was for $\$ 3$ billion for home care over four years..$^{95}$ At their January 2016 meeting, the federal, provincial and territorial health ministers did agree that improving the affordability and accessibility of prescription drugs is a shared priority and Philpott agreed to join a federal-provincialterritorial working group..$^{96}$

A main concern of the PT governments has been the impending reduction in the Canada Health Transfer (CHT) to three per cent in 2017-18. At their summer 2016 meeting, the premiers called for a meeting with the prime minister to develop a long-term agreement on health-care funding, and they also stressed that any new accord would have to respect the principle of asymmetrical federalism. ${ }^{97}$ PT finance and health ministers repeated the call prior to their meeting with Philpott on Oct. 17, 2016.98

The ministers of finance and health from the two levels of government met again on Dec. 19, 2016. The PT ministers pushed for a 5.2-per-cent CHT escalator, ${ }^{99}$ and the federal

93 ibid.

94 S. Morgan et al., "Estimated effects of adding universal public coverage of an essential medicines list to existing public drug plans in Canada," Canadian Medical Association Journal 189 (February 27, 2017): E295-302.

95 Liberal Party of Canada, "Investing."

96 Conference of Federal-Provincial-Territorial Ministers of Health, news release, January 21, 2016, http://www.scics.ca/en/ product-produit/news-release-statement-of-the-federal-provincial-territorial-ministers-of-health/.

97 Council of the Federation, "Health care sustainability," news release, July 22, 2016, http://www.canadaspremiers.ca/ phocadownload/newsroom_2016/health_care_sustainability_july22.pdf.

98 Conference of Provincial-Territorial Ministers of Health, "Finance and health ministers seek funding partnership with the federal government," news release, October 17, 2016, http://www.scics.ca/en/product-produit/news-release-finance-andhealth-ministers-seek-funding-partnership-with-the-federal-government/.

99 Bruce Campion-Smith, "Health talks fail despite federal pledges of more cash for home care, mental health," Toronto Star, December 19, 2016, https:/www.thestar.com/news/canada/2016/12/19/provinces-reject-ottawas-pitch-on-healthcare.html. 
government offered 3.0 per cent plus $\$ 11.5$ billion over 10 years for home care, mental health and initiatives on prescription drugs and health innovation. ${ }^{100}$ The meeting concluded with no deal, but on Dec. 22 it was announced that an agreement had been reached with New Brunswick, whereby the province would get its share (per capita) of the $\$ 11.5$ billion $^{101}$ and, since then, all other jurisdictions have signed deals with the federal government, with the exception of Manitoba. ${ }^{102}$ While the PBO 2016 Fiscal Sustainability Report made the case that federal fiscal prospects remain brighter than those of the PTs (reporting the federal fiscal gap at -0.9 per cent of GDP, versus a PT gap of 1.5 per cent of GDP), ${ }^{103}$ the Department of Finance issued a report in December projecting that the federal government could run deficits until 2055-56. ${ }^{104}$ Hence, the prospect of a federal contribution to a pharmacare program, even a partnership model, seems highly unlikely for the foreseeable future, at least for the duration of the government's current mandate.

\section{Winners and Losers}

In her testimony to HESA Dr. Danielle Martin noted "We have to understand that there's a lot of money in the drug industry in Canada and that there are always going to be winners and losers in every transition. We need to look to you as political leaders to show leadership in the politics of the transition." 105 It is important to understand who the winners and losers are, both from the perspective of likely support — and likely opposition — to policy proposals, but also from the standpoint of the side effects that a pharmacare program might create. The most obvious losers in the proposals for single-payer public pharmacare are the brand name and generic pharmaceutical industries as a result of price reductions and the private insurance industry, and the most obvious winner is ultimately expected to be the patient/taxpayer. One question that has not been examined to any degree over the course of the various pharmacare proposals is how viable the supplementary-health-benefits industry would be if a public pharmacare program were to be put in place.

According to CLHIA, the $\$ 32.2$ billion paid out in supplementary health-insurance benefits in 2015 was distributed as follows:

- Prescription drugs - 33 per cent

- Dental care - 24 per cent

- Paramedic and vision - nine per cent

- Hospital accommodation - six per cent

- Travel insurance - three per cent

100 Department of Finance, "Federal Proposal to Strengthen Health Care for Canadians," http://www.fin.gc.ca/n16/data/16161_1-eng.asp.

101 Government of Canada, "Canada-New Brunswick reach agreement on funding for health accord," news release, December 22, 2016, http://news.gc.ca/web/article-en.do?nid=1173099.

102

Health Canada, "Canada reaches health funding agreement with Ontario," news release, March 10, 2017, https://www.canada.ca/en/health-canada/news/2017/03/canada_reaches_healthfundingagreementwithontario.html.

103 Office of the Parliamentary Budget Officer, "Fiscal Sustainability Report 2016” (June 28, 2016), http://www.pbo-dpb.gc.ca/ web/default/files/Documents/Reports/2016/FSR_2016/FSR_2016_EN.pdf.

104 Department of Finance, "Update of long-term economic and fiscal projections 2016," https://www.fin.gc.ca/pub/ltefp-peblt/ pdf/ltefp-peblt-eng.pdf.

105 Standing Committee on Health, evidence, April 18, 2016. 
- Disability - 21 per cent

- Other - four per cent ${ }^{106}$

With prescription drugs comprising one-third of the business, this question warrants attention. In responding to a question at the HESA hearings about the impact of a public pharmacare program on the private health insurance industry, CLHIA's president, Frank Swedlove, answered: "there are a number of companies that operate exclusively in the supplementary health business. Of course they can continue to offer the non-drug portion, but their business would be affected." ${ }^{\prime 107}$ He continued on to single out Blue Cross and other not-for-profit firms.

This was reinforced by the testimony of Diane Balon of Alberta Blue Cross to HESA on Feb. 2, 2017. Noting that the HESA study focuses on pharmacare, she said "any changes to the funding model for drug coverage should consider the potential implications that it could have to the coverage level for other benefits. These benefits include things like diabetic supplies, psychology services, physiotherapy benefits, wellness initiatives, and a host of other medical services that address individuals' health needs holistically."108

Clearly this would require further study, but at one-third of the supplementary-healthbenefits business, prescription drug insurance supports a large infrastructure that serves as a backbone for all supplementary benefits. Removal of prescription drugs would require a rescaling of the health insurance business. It would be of particular concern if there were any implications for dental insurance coverage, which represented one-fourth of the business in 2015. Analysis of Statistics Canada's 1996/97 National Population Health Survey showed that 73 per cent of individuals with dental insurance had visited a dentist in the past year, compared with 45 per cent of those without dental insurance. ${ }^{109}$ Attention to the importance of oral health is growing, ${ }^{110}$ and yet access to dental care is simply not on the policy agenda. As shown in Table 1, with six-per-cent public funding of dental-office visits in 2012, Canada was almost six times below the OECD average for 22 countries.

Another aspect of winners and losers has been the recent furor over a story appearing in the National Post on Dec. 3, 2016 citing unnamed sources who indicated that the federal government is considering taxing private health and dental plans. Their tax exemption is projected to result in a tax expenditure costing the government $\$ 2.9$ billion in 2017. ${ }^{111}, 112$ This tax reform was most recently proposed by the Advisory Panel on Healthcare

106 Canadian Life and Health Insurance Facts (Canadian Life and Health Insurance Association, 2016), https://www.clhia.ca/ domino/html/clhia/CLHIA_LP4W_LND_Webstation.nsf/resources/Factbook_2/\$file/2016+CLHIA+Factbook+ENG.pdf.

107 Standing Committee on Health, evidence, May 9, 2016.

108 House of Commons Standing Committee on Health, evidence, February 2, 2017, http://www.parl.gc.ca/content/hoc/ Committee/421/HESA/Evidence/EV8729943/HESAEV39-E.PDF.

109 W. Millar and D. Locker, "Dental insurance and use of dental services," Health Reports 11, 1 (1999): 55-67.

110 A. Weil, "Oral health,” Health Affairs 35, 12 (2016): 2163.

111 John Ivison, "Liberals eye tax on private health and dental plans, a move that would take in about \$2.9 B," National Post, December 3, 2016, http://news.nationalpost.com/news/canada/canadian-politics/federal-liberals-eye-tax-on-private-healthand-dental-plans-to-take-in-about-2-9b.

112 Department of Finance, "Report on federal tax expenditures 2016," https://www.fin.gc.ca/taxexp-depfisc/2016/taxexpdepfisc16-eng.pdf. 
Innovation, ${ }^{113}$ and Gagnon had included the elimination of the tax subsidy as an offsetting measure in his 2010 proposal. This resulted in an immediate reaction from stakeholders, primarily based on a study of the Quebec decision to treat the employer contribution to health and dental benefits as taxable income beginning in 1993. The study found that this measure resulted in a 13 -to 14-percentage-point drop in workplace coverage in the province. ${ }^{114}$ A coalition of eight health-professional associations who would be impacted by any measure that would reduce employer-provided health insurance launched a campaign called "Don't Tax My Health Benefits," which invited the public to write to their member of Parliament (MP). The website indicates that more than 80,000 Canadians have done so. ${ }^{115}$ Similarly, the Canadian Chamber of Commerce created a template email for its members to send to the federal finance minister and their MP. ${ }^{116}$ The Canadian Federation of Independent Business has provided a bulletin to its members outlining the implications of the potential tax measure and encouraging them to visit the coalition's website. ${ }^{117}$

The coalition subsequently commissioned research from the Conference Board of Canada that was pre-released in the National Post on Jan. 29. It suggested that middle-income earners (in receipt of employer-sponsored health benefits) will pay an additional $\$ 1,000$ in federal and provincial income tax should the taxation of health and benefits go through. ${ }^{118}$, ${ }^{119}$ This led to a question in the House of Commons on Feb. 1 by interim Conservative Leader Rona Ambrose as to why the government would even consider such a tax. In his reply, Prime Minister Justin Trudeau answered "we are committed to protecting the middle class from increased taxes and that is why we will not be raising the taxes the member opposite proposes we will do". ${ }^{120}$

On Feb. 2 the Conservative party introduced the following motion: "That, given the average middle class Canadian is already overburdened with taxes, the House call on the government to abandon any plans it may have to in any way tax health and dental care plans." ${ }^{21}$ During the debate over the issue, the parliamentary secretary to the government leader in the House of Commons stated that "the Prime Minister and his government have

113 "Advisory Panel on Healthcare Innovation. Unleashing Innovation: Excellent Healthcare for Canada" (Advisory Panel on Healthcare Innovation, 2015), http://www.healthycanadians.gc.ca/publications/health-system-systeme-sante/reporthealthcare-innovation-rapport-soins/alt/report-healthcare-innovation-rapport-soins-eng.pdf.

114 A. Finkelstein, "The effect of tax subsidies to employer-provided supplementary health insurance: evidence from Canada," Journal of Public Economics 84 (2002): 305-39.

115 See http://donttaxmyhealthbenefits.ca/.

116 Canadian Chamber of Commerce website, "Hot Topic: Taxation of Employer-paid Health and Dental Benefits," http://www.chamber.ca/advocacy/taxation-of-employer-paid-benefits/, accessed February 9, 2017.

117 Canadian Federation of Independent Business website, "Federal government looking at making employer-sponsored health and dental benefits taxable," http://www.cfib-fcei.ca/english/article/9140-healthanddentalbenefits.html, accessed February $10,2017$.

118 John Ivison, "Millions of Canadians will pay at least $\$ 1,000$ more if Ottawa taxes health and dental plans, study finds," National Post, January 29, 2017, http://news.nationalpost.com/full-comment/john-ivison-millions-of-canadians-will-pay-atleast-1000-more-if-ottawa-taxes-health-and-dental-plans-study-finds.

119 Alexandru Dobrescu, "The implications of taxing employer-paid health and dental benefits" (Conference Board of Canada, February 13, 2017), http://www.conferenceboard.ca/temp/3eb0ba82-0f10-4f06-9906-ddfbc6f6e06f/8612_taxing-employerpaid-benefits_br_pdf.

${ }^{120}$ Canada. House of Commons, debates, February 1, 2017, http://www.parl.gc.ca/content/hoc/House/421/Debates/131/ HAN131-E.PDF.

121 Canada. House of Commons, debates, February 2, 2017, http://www.parl.gc.ca/content/hoc/House/421/Debates/132/ HAN132-E.PDF. 
been very clear. There is not going to be a tax on health and dental plans." 122 The motion was subsequently defeated on Feb. 7 by a vote of 175 to $138 .{ }^{123}$ There was no mention of such a measure in the 2017 Budget, hence it is off the table for the time being.

\section{State of Public and Employer Opinion}

Since 2012, at least eight national public opinion surveys and three employer surveys have been conducted that have asked questions pertinent to pharmacare. The findings suggest several key observations.

- Pharmacare is not a "top-of-mind" issue for most Canadians. A 2012 survey by Ekos Research Associates found that, when asked an open-ended question about the most important issue facing Canadians today, cost of health care/medication ranked fourth at seven per cent, well behind the top three, which all related to access and wait times and accounted for 40 per cent of the respondents. When asked about how serious a problem they thought each of 10 issues is with respect to Canadians' health and the health-care system, lack of access to prescription medication ranked $10^{\text {th }}$, with 47 per cent rating it as a serious problem compared with the top-ranked 83-per-cent rating for the increasing demands on the system resulting from an aging population. ${ }^{124}$ Similar results were obtained in 2016 surveys by Pollara ${ }^{125}$ and Ipsos. ${ }^{126}$

- Nonetheless, when asked about pharmacare, Canadians agree that it is a good idea. A 2015 survey by the Angus Reid Institute found that almost nine in 10 (88 per cent) agreed that "every Canadian — regardless of income - should have access to necessary prescription medicine" and there was a similar level of support for adding prescription drugs to medicare. ${ }^{13}$ Similar support is found in surveys by Abacus Data $(2015)^{127}$ and Ekos Research Associates (2016). ${ }^{128}$

- Canadians value employer-provided supplementary health benefits. A 2012 survey by Ipsos found that among those with such benefits, four in 10 (42 per cent) indicated that benefits would be a factor in deciding whether to switch jobs, ${ }^{129}$ and a 2016 survey by Ipsos found that 70 per cent of respondents were opposed to the taxation of health and dental benefits. ${ }^{130}$

122 House of Commons, debates, February 1, 2017.

123 Canada. House of Commons, debates, February 7, 2017, http://www.parl.gc.ca/content/hoc/House/421/Debates/135/ HAN135-E.PDF.

124 "Detailed Tables from Health and Health Care in the 21 ${ }^{\text {st }}$ Century: Wave 1" (Ekos Research Associates Inc., May 2012).

125 "Health Care in Canada, 2016 Results: Trends" (McGill University, 2016), http://www.mcgill.ca/hcic-sssc/files/hcic-sssc/ hcic_2016_results_01-trends.pdf.

126 " $16^{\text {th }}$ Annual National Report Card on Health Care" (Canadian Medical Association, August 18, 2016), https://www.cma.ca/ En/Lists/Medias/16th_Annual_National_Report_Card-on_Health_Care_en.pdf.

127 "National Pharmacare in Canada" (Abacus Data, July 2015), http://www.pharmacists.ca/cpha-ca/assets/File/pharmacy-incanada/Pharmacare\%20Survey\%20Results_July\%202015.pdf.

128 "Canadian attitudes toward health issues" (Ekos Research Associates Inc., 2016), https://nursesunions.ca/sites/default/files/ cfnu_2016_survey_findings.pdf.

129 Ipsos Reid, “Two in ten (18\% per cent) Canadians have no supplementary coverage," press release, http://www.ipsos-na. com/news-polls/pressrelease. aspx?id=5714.

130

Canadian Dental Association, "Health care providers urge federal government to not tax health benefit plans," news release December 21, 2016, https://www.cda-adc.ca/en/about/media_room/canadian_dentistry_news/articles/2016/122016.asp. 
- Surveys indicate contradictory support for how pharmacare should be implemented. The 2015 Abacus Data survey found that, when presented with three options for a pharmacare program, almost one in two respondents (46 per cent) supported a program that would cover Canadians who are not currently covered by a government or private plan; almost one in three (31 per cent) supported a single program that would replace all existing government and private plans; and just over one in five (21 per cent) supported a program that would only cover Canadians facing extreme circumstances such as expensive drugs for rare diseases. ${ }^{131}$ In contrast, the 2016 Pollara survey found that, when asked to select the best approach for ensuring that all Canadians have access to prescription medications from among three options, 39 per cent chose a single national public pharmacare plan operated by the federal government and funded by taxes collected by the federal government; 19 per cent chose separate regional pharmacare plans in each province and territory, funded by taxes collected by both the federal government and the provincial governments; 17 per cent chose private prescription plans operated by private insurance companies, supplemented by a public prescription drug plan provided by the federal government for persons with high out-of-pocket drug costs; and 25 per cent chose "don't know." 132

- Employers value the provision of supplementary benefits as a competitive edge for attracting employees. A 2012 employer survey by Ipsos Reid found that more than eight out of 10 ( 85 per cent) employers indicated that even if the government introduced a pharmacare program, they would still recommend that their business offer supplementary benefits as it would provide an advantage in recruiting and retaining employees. ${ }^{133}$ Aon Hewitt reported a similar finding on a 2015 employer survey. ${ }^{134}$

- Like the population surveys, the two 2015 employer surveys show contradictory evidence about the level of support for how pharmacare should be implemented. The Aon Hewitt survey found that almost nine in 10 (88 per cent) agreed that a governmentrun program with principles similar to the Canada Health Act would be a positive solution, ${ }^{135}$ while a Benefits Canada survey found that almost nine in 10 (87 per cent) supported "a publicly funded national catastrophic drug program to take some of the cost pressures off plan sponsors," while just over one in two (53 per cent) indicated support for a "government funded, national pharmacare program for all Canadians to replace current provincial and private drug benefit programs such as yours." ${ }^{\prime 136}$

In summary, while the survey results show strong support among the public and employers for all Canadians having access to prescription drugs, the evidence is much less clear on how it should be implemented and how it should be funded. Should governments want to take this issue on, they would be well advised to consider a deliberative consultation

\footnotetext{
131 "National Pharmacare," Abacus.

132 "Health Care in Canada, 2016 Results: Looking Forward" (McGill University, 2016), http://www.mcgill.ca/hcic-sssc/files/ hcic-sssc/hcic_2016_results_10-looking_forward.pdf.

133 “16 $6^{\text {th }}$ Annual," Canadian Medical Association.

134 "Pharmacare in Canada" (Aon Hewitt, 2016), http://www.aon.ca/surveys/rr/Aon_Pharm_2016_EN.pdf.

135 ibid.

136 "Face to Face in Drug Plan Management: Research Results," Benefits Canada, conference presentation, December 2, 2015.
} 
process much like the federal government did in the 1990s on the future of the Canada Pension Plan, which resulted in increases to contribution rates. ${ }^{137}$

\section{One Other Issue: First-Dollar Coverage?}

As the HESA study progresses, one issue that bears examination is the feasibility/ affordability of first-dollar coverage for prescription drugs. It would seem that it has been implicitly assumed that some level of co-payment would be required for prescription drugs; as noted previously, the Hall report recommended a \$1.00 charge in 1964. In England, which does include drugs in the National Health Service (NHS), the current prescription charge is 8.40 pounds, although 90 per cent of prescription items are provided free of charge. ${ }^{138,139}$ Appleby has noted, however, that in Wales, Northern Ireland and Scotland, the NHS has eliminated prescription charges. ${ }^{140}$ One observational study of dispensing rates in Wales found that the overall impact of removing prescription charges was minimal. ${ }^{141}$ Table 3 is only a superficial look at the volume of prescriptions dispensed in Scotland from 200915, years that straddle the removal of prescription charges on April 1, 2011, but it indicates that, after 2012, the growth in annual volumes dispensed began to diminish. It should be added, however that patient charges accounted for less than four per cent of dispensing expenditures in 2010. ${ }^{142}$ The experience of these jurisdictions merits closer investigation.

TABLE 3 PRESCRIPTION DISPENSING IN SCOTLAND, 2009-15

\begin{tabular}{|c|c|c|}
\hline Year & $\begin{array}{c}\text { Number of Prescriptions } \\
\text { (million) }\end{array}$ & \% increase from previous year \\
\hline 2009 & 88.4 & 3.8 \\
\hline 2010 & 91.0 & 3.0 \\
\hline 2011 & 93.8 & 3.1 \\
\hline 2012 & 96.6 & 3.0 \\
\hline 2013 & 98.4 & 1.9 \\
\hline 2014 & 100.6 & 2.2 \\
\hline 2015 & 102.0 & 1.4 \\
\hline
\end{tabular}

Source: Annual tabulations: Remuneration and reimbursement details for all prescribing made in Scotland.

\footnotetext{
137 "Report on the Canada Pension Plan Consultations," Federal/Provincial/Territorial CPP Consultations Secretariat (June 1996), http://publications.gc.ca/collections/Collection/F2-108-2-1996E.pdf.

138 United Kingdom. National Health Service website, "NHS in England - help with health costs," http://www.nhs.uk/ NHSEngland/Healthcosts/Pages/Prescriptioncosts.aspx.

139 United Kingdom. Health and Social Care Information Centre, "Fast facts: prescribing," https://www.gov.uk/government/ uploads/system/uploads/attachment_data/file/366544/Prescibing_FINAL.pdf.

140 J. Appleby, "Prescription charges: are they worth it?” British Medical Journal 34 (2014): g3944 doi: 10.1136/bmj.g3944.

141 D. Cohen et al., "Abolition of prescription copayments in Wales: an observational study on dispensing rates," Value in Health 13, 5 (2010): 675-80.

142 United Kingdom. Information Services Division, Scotland, website, "Prescribing and medicines. Data tables," https://isdscotland.scot.nhs.uk/Health-Topics/Prescribing-and-Medicines/Publications/data-tables.asp?id=1382\#1382, accessed February 25, 2017.
} 


\section{Conclusion}

In conclusion, the answer to the question "has the time come for national pharmacare?" is "not yet" - at least not within the current mandate of the federal government. Whatever ultimate savings might be obtained from bulk purchasing and generic prescribing, in the short to medium term there will be transition costs to government that greatly exceed the $\$ 11.5$ billion that the federal government has put forward for the next 10 years (on top of the $3 \%$ increase in the CHT). Even the incremental proposals most recently costed by the Conference Board and Morgan et al. exceed this amount (assuming an annual average of $\$ 1.15$ billion). Moreover, the emergence of bilateral agreements and the emphasis on asymmetrical federalism would seem to run counter to the establishment of new national standards in the health-care arena. Considering the proposals put forward, the plan put forward by Kirby in 2002 still seems to be the most workable approach for a cost-shared scalable scheme between the federal and provincial/territorial governments and private drug plans that would constitute a step toward a national plan. The prodigious efforts of those who have opened a policy window that has led to the HESA study are to be commended, and hopefully that report will lead to serious deliberation about universal access to prescription drugs, possibly in the campaign leading up the federal election slated for October 2019. Finally, we must bear in mind that in order to sustain any drug program, it will be essential to address a broader array of elements of a pharmaceutical strategy, as originally set out in the Hall report and, more recently, in the 2004 health accord.

March 23, 2017 


\section{APPENDIX A \\ PROPOSALS/MODELS AND ESTIMATES OF PUBLIC FUNDING FOR PHARMACARE 1964-2017}

1964 - Royal Commission on Health Services (Hall). Federal government would cover 50 per cent of the cost of a drug benefit program. $\$ 1.00$ prescription charge. It was estimated that this would require public funding of $\$ 163$ million in 1966, from a base cost of essentially zero.

1971-72 - Health ministers develop a drug price program that would extend medicare to prescription drugs (source is archival memoranda reviewed by Boothe).

1997 - National Forum on Health. "Expand publicly funded services to include all medically necessary services, and, in the first instance, home care and drugs." As 1994 was cited as the reference year, this would have required an increase of $\$ 3.5$ billion in public funding on top of the existing $\$ 3.0$ billion in public funding.

1997 - Palmer D’Angelo Consulting Inc. Developed seven models with variations on public/private and level of co-payment. Public funding in 1996 was $\$ 3.0$ billion. Public noco-payment model would increase public funding by $\$ 4.3$ billion. Public/private model with patient paying dispensing fee would increase public funding by $\$ 217$ million.

2002 - Palmer D'Angelo Consulting Inc. Updated the seven models developed in 1997, to 2001. Public funding in 2001 was $\$ 5.5$ billion. Public no-co-payment model would increase public funding by $\$ 8.1$ billion. Public/private model with patient paying dispensing fee would increase public funding by $\$ 1.2$ billion.

2002 - Royal Commission on the Future of Health Care in Canada (Romanow). Recommended a catastrophic-drug transfer of $\$ 1.0$ billion (modelled on Manitoba's experience) that would reimburse 50 per cent of the costs of provincial and territorial public drug plans above a threshold of $\$ 1,500$ per person, per year.

2002 - Standing Senate Committee on Social Affairs, Science and Technology (Kirby). Recommended that the federal government pay 90 per cent of costs above $\$ 5,000$ for individuals covered by provincial-territorial drug plans, with family drug expenditures capped at three per cent of total family income. A similar provision would apply to private insurance plans with the stipulation that individual plan member's costs would be capped at the lesser amount of three per cent of family income or $\$ 1,500$. Estimated to cost $\$ 500$ million per year.

2006 - National Pharmaceuticals Strategy (NPS) Progress Report. Developed four models of catastrophic coverage based on variations of a variable/fixed percentage of catastrophic costs and income threshold and whether the public plan would take over catastrophic coverage from private plans. Base public funding assumed to be $\$ 6.6$ billion. Estimates of increased public funding ranged from $\$ 1.4$ billion, for a model that would cover catastrophic spending for public plans only with a fixed 4.3-per-cent threshold, to $\$ 4.7$ billion for a model that would cover catastrophic spending for public and private plans with a variable percentage threshold scaled to income.

2008 - Provincial-territorial health ministers. Apparently building on the 2006 NPS report, estimated the cost of a catastrophic drug program at $\$ 5.03$ billion for 2006, 
assuming a cap of five per cent of net income and proposed 50/50 cost sharing with the federal government.

2010 - Marc-André Gagnon. Developed four scenarios for full public funding on a base of $\$ 11.2$ billion in public funding in 2008. Scenario 1: Based on current industry policies, would require $\$ 12.5$ billion in additional public funding. Scenario 4: With savings from competitive purchasing, policies would require $\$ 4.7$ billion in additional public funding.

2014 - Marc-André Gagnon. Updated scenarios 1 and 4 based on a 2012 base of $\$ 11.8$ billion in public funding. Scenario 1: Based on current industry costs, policies would require $\$ 15.8$ billion in additional public funding. Scenario 4: With savings from competitive purchasing, policies would require $\$ 7$ billion in additional public funding.

2015 - Steve Morgan and colleagues. Developed three scenarios of public pharmacare with modest co-payments on a $2012-13$ base of $\$ 12.2$ billion in public funding, by varying parameters of brand-name and generic prices, changes in product selection within drug classes, and changes in utilization. In the base scenario, public funding would increase by $\$ 958$ million; the worst-case scenario would increase public funding by $\$ 5.3$ billion; and the best-case scenario would decrease public funding by $\$ 2.9$ billion.

2015 - Conference Board of Canada. Modelled the cost of a public catastrophic-drug program that would cover all public- and private-plan expenditures above a threshold of $\$ 1,500$ or three per cent of gross household income. This was estimated to cost $\$ 1.6$ billion in 2016, rising to $\$ 1.8$ billion by 2020 .

2016 - PDCI Market Access Inc. Updated the four public-only models from 1997 and 2002 on a 2015 public-expenditure base of $\$ 11.3$ billion and developed three models of pharmacare for the uninsured assuming continued existing public-private coverage. Public no-co-payment model would increase public funding by $\$ 16.0$ billion. Among the three models of pharmacare for the uninsured, a modified Quebec program would increase public funding by $\$ 2.2$ billion, a P.E.I. generic-drug-plan model would increase public funding by $\$ 93$ million, and a private model would increase private insurance funding by $\$ 2.3$ billion.

2017 - Morgan et al. Developed three scenarios for the introduction of universal public coverage of 117 essential medicines on a 2015 public-expenditure base of \$10.8 billion. Depending on assumptions of changes in utilization and prices of brand-name and generic essential medicines, public expenditure would increase by $\$ 1.2$ billion and private expenditure would decrease by $\$ 4.3$ billion. The worst-case scenario would increase public funding by $\$ 1.9$ billion and the best case would increase it by $\$ 373$ million. 


\section{APPENDIX B}

\section{PROFILE OF WITNESSES AND BRIEFS PRESENTED TO THE STANDING COMMITTEE ON HEALTH (HESA) IN ITS STUDY OF NATIONAL PHARMACARE: APR. 13, 2016 TO FEB 2, 2017}

\begin{tabular}{|c|c|c|c|c|c|c|}
\hline & Government & $\begin{array}{l}\text { Appearing as } \\
\text { Individuals }\end{array}$ & $\begin{array}{c}\text { Health Professionals/ } \\
\text { Organizations }\end{array}$ & $\begin{array}{l}\text { Health Charities } \\
\text { and Patient Groups }\end{array}$ & Industry & Other \\
\hline \multirow{11}{*}{$\begin{array}{c}\text { Presented as a } \\
\text { witness before the } \\
\text { committee }\end{array}$} & $\begin{array}{l}\text { Patented Medicines } \\
\text { Prices Review Board } \\
\text { (PMPRB) }\end{array}$ & Steve Morgan (UBC) & $\begin{array}{c}\text { Canadian Pharmacists } \\
\text { Association }\end{array}$ & $\begin{array}{c}\text { Canadian Association } \\
\text { of Retired Persons }\end{array}$ & $\begin{array}{l}\text { Canadian Life and } \\
\text { Health Insurance } \\
\text { Association (CLHIA) }\end{array}$ & C.D. Howe Institute \\
\hline & $\begin{array}{l}\text { Canadian Agency for } \\
\text { Drugs and Technology } \\
\text { in Health (CADTH) }\end{array}$ & $\begin{array}{c}\text { Christopher McCabe (U } \\
\text { of Alberta) }\end{array}$ & $\begin{array}{l}\text { Canadian Federation } \\
\text { of Medical Students }\end{array}$ & Arthritis Society & $\begin{array}{l}\text { Consumer Health } \\
\text { Products Canada }\end{array}$ & 3Sixty Public Affairs \\
\hline & $\begin{array}{l}\text { Canadian Institute for } \\
\text { Health Information } \\
(\mathrm{ClHI})\end{array}$ & Robyn Tamblyn (McGill) & $\begin{array}{c}\text { Women's College } \\
\text { Hospital } \\
\text { (Danielle Martin) }\end{array}$ & $\begin{array}{c}\text { Heart and Stroke } \\
\text { Foundation of Canada }\end{array}$ & $\begin{array}{c}\text { Innovative } \\
\text { Medicines Canada }\end{array}$ & Surrey Board of Trade \\
\hline & $\begin{array}{l}\text { Office of the } \\
\text { Parliamentary } \\
\text { Budget Officer }\end{array}$ & $\begin{array}{l}\text { Gregory Marchildon } \\
\text { (U of Toronto) }\end{array}$ & $\begin{array}{c}\text { UBC Therapeutics } \\
\text { Initiative }\end{array}$ & $\begin{array}{l}\text { Citizens' Reference } \\
\text { Panel on Pharmacare }\end{array}$ & $\begin{array}{c}\text { Canadian Generic } \\
\text { Pharmaceutical } \\
\text { Association }\end{array}$ & Roy Romanow \\
\hline & $\begin{array}{c}\text { Health Canada Strategic } \\
\text { Policy Branch }\end{array}$ & $\begin{array}{l}\text { Colleen Flood } \\
\text { (U of Ottawa) }\end{array}$ & & & BIOTECanada & \\
\hline & $\begin{array}{l}\text { Health Canada } \\
\text { First Nations and Inuit } \\
\text { Health Branch }\end{array}$ & $\begin{array}{c}\text { Mélanie Bourassa } \\
\text { Forcier (U Sherbrooke - } \\
\text { CIRANO) }\end{array}$ & & & PCDI Market Access & \\
\hline & $\begin{array}{l}\text { Dapartment of } \\
\text { National Defence }\end{array}$ & $\begin{array}{l}\text { Doug Coyle } \\
\text { (U of Ottawa) }\end{array}$ & & & Alberta Blue Cross & \\
\hline & $\begin{array}{l}\text { Office of the Auditor } \\
\text { General of Canada }\end{array}$ & Larry Lynd (UBC) & & & & \\
\hline & $\begin{array}{l}\text { Department of } \\
\text { Veteran Affairs }\end{array}$ & $\begin{array}{l}\text { Anne Holbrook } \\
\text { (McMaster) }\end{array}$ & & & & \\
\hline & & $\begin{array}{l}\text { David Henry } \\
\text { (U of Toronto) }\end{array}$ & & & & \\
\hline & & $\begin{array}{c}\text { Marie-Claude } \\
\text { Prémont (ENAP) }\end{array}$ & & & & \\
\hline \multirow{4}{*}{ Submitted a Brief } & $\begin{array}{l}\text { Canadian Institutes of } \\
\text { Health Research }\end{array}$ & David West & & $\begin{array}{l}\text { Independent Patient } \\
\text { Voices Network } \\
\text { of Canada }\end{array}$ & $\begin{array}{l}\text { Cannabis Canada } \\
\text { Associaiton }\end{array}$ & $\begin{array}{l}\text { Canadian Labour } \\
\text { Congress }\end{array}$ \\
\hline & & Mary Lou Robertson & & $\begin{array}{l}\text { Canadian Cancer } \\
\text { Survivor Network }\end{array}$ & & $\begin{array}{c}\text { Canadian Institute } \\
\text { of Actuaries }\end{array}$ \\
\hline & & & $\begin{array}{c}\text { Registered Nurses } \\
\text { Association of Ontario }\end{array}$ & $\begin{array}{l}\text { Mood Disorders } \\
\text { Society of Canada }\end{array}$ & & \\
\hline & & & & $\begin{array}{c}\text { Union des } \\
\text { consommateurs }\end{array}$ & & \\
\hline \multirow{4}{*}{$\begin{array}{l}\text { Both (testified and } \\
\text { submitted a brief) }\end{array}$} & Health Quality Ontario & $\begin{array}{l}\text { Marc André Gagnon } \\
\text { (Carleton) }\end{array}$ & $\begin{array}{c}\text { Canadian Nurses } \\
\text { Association }\end{array}$ & $\begin{array}{l}\text { Canadian Organization } \\
\text { for Rare Disorders }\end{array}$ & & Angus Reid Institute \\
\hline & $\begin{array}{l}\text { Canadian Blood } \\
\text { Services }\end{array}$ & $\begin{array}{l}\text { Matthew Herder } \\
\text { (Dalhousie) }\end{array}$ & $\begin{array}{l}\text { Canadian Medical } \\
\text { Association }\end{array}$ & $\begin{array}{c}\text { Canadian Diabetes } \\
\text { Association }\end{array}$ & & $\begin{array}{l}\text { Canadian Union of } \\
\text { Public Employees }\end{array}$ \\
\hline & & $\begin{array}{l}\text { Katherine Boothe } \\
\text { (McMaster) }\end{array}$ & $\begin{array}{l}\text { Canadian Doctors } \\
\text { for Medicare }\end{array}$ & $\begin{array}{l}\text { Health Charities } \\
\text { Coalition of Canada }\end{array}$ & & $\begin{array}{l}\text { Canadian Health } \\
\text { Coalition }\end{array}$ \\
\hline & & & $\begin{array}{l}\text { Canadian Federation } \\
\text { of Nurses Unions }\end{array}$ & & & \\
\hline
\end{tabular}




\section{APPENDIX C \\ STANDING COMMITTEE ON HEALTH: REQUEST TO THE OFFICE OF THE PARLIAMENTARY BUDGET OFFICER, SEPTEMBER 29, 2016}

It was agreed, - That the motion adopted Tuesday, September 27, 2016, concerning the Parliamentary Budget Officer be rescinded and replaced with the following: "That the Committee request the Parliamentary Budget Officer to provide it with an analysis of the following items by (specify date based on PBO's estimate of earliest date this analysis can reasonably be completed):

a. The total number and percentage of Canadians:

i. who are ineligible for full public coverage of all prescription pharmaceuticals outside of hospitals (under current provincial and federal programs), excluding catastrophic coverage, and who do not have equivalent private or employer sponsored coverage; and ii. whose private or employer-sponsored coverage has been reduced or eliminated in the past 10 years.

b. Estimate the current Canadian annual total of:

i. employer contributions to employer-sponsored private insurance benefit plans in respect of prescription pharmaceutical coverage;

ii. employee contributions to employer-sponsored private insurance benefit plans in respect of prescription pharmaceutical coverage;

iii. total out-of-pocket payments by patients for prescription pharmaceuticals;

iv. direct and indirect government subsidies to private pharmaceutical insurance plans;

v. expenditure on prescription pharmaceuticals broken down by province or territory and by source of funding;

vi. individual expenditure on private pharmaceutical insurance coverage;

and where possible, broken down by province or territory, by urban/rural, by age quintile and by annual household income quintile, for all of the above information.

c. Estimate the cost of (1) creating and (2) administering:

i. a single-payer universal first-dollar prescription drug coverage under the Canada Health Act; and

ii. a single purchaser and national distribution system for prescription drugs, possibly modeled on the Canadian Blood Services and/or other relevant models in Canada or other jurisdictions.

d. Assume that there is a single national formulary for prescription drugs with tiers based on the relative importance of the health condition treated, and the relative effectiveness of the drug in addressing the health condition, ranging from essential medicines for tier 1 , and then proceeding to drugs that are less essential or equivalent but more costly in subsequent tiers. 
In terms of the financing of a single-payer prescription drug coverage program, analyze the efficiency of an:

i. introduction of a payroll tax;

ii. increase in sales tax;

iii. increase in corporate and/or personal income tax; and

iv. introduction of a co-pay based on France's SMR/ASMR model.

e. Discuss the implications of and the tools available for raising any additional revenue needed to finance such a program.

f. To the extent possible:

i. estimate of the total annual savings to the health care system from eliminating costrelated non-adherence to pharmaceutical prescriptions in Canada;

ii. estimate of the total annual savings achievable by a single-payer, as opposed to the present multiplicity of public and private payers, acting as the sole original purchaser of prescription pharmaceuticals in Canada; and

iii. estimate of the total annual savings from bulk buying, exclusive licensing, increased use of generic medicines, and evidence-based formulary.

In carrying out this analysis, the PBO will work with Canadian Institutes for Health Information, Statistics Canada, Canadian Agency for Drugs and Technology in Health, IMS Brogan and other sources to obtain appropriate data. The PBO's report will disclose in detail the sources of data, the quality of the data and the methods of analysis used".

House of Commons Standing Committee on Health. Minutes of proceedings, Meeting No. 21 September 29, 2016.

http://www.parl.gc.ca/HousePublications/Publication.

aspx? Language $=\mathrm{e} \&$ Mode $=1 \& \operatorname{Parl}=42 \&$ Ses $=1 \&$ DocId $=8462385$. 


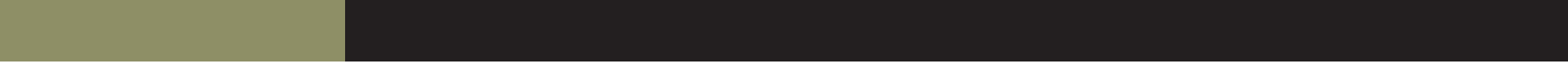




\title{
ABOUT THE SCHOOL OF PUBLIC POLICY
}

The School of Public Policy has become the flagship school of its kind in Canada by providing a practical, global and focused perspective on public policy analysis and practice in areas of energy and environmental policy, international policy and economic and social policy that is unique in Canada.

The mission of The School of Public Policy is to strengthen Canada's public service, institutions and economic performance for the betterment of our families, communities and country. We do this by:

- Building capacity in Government through the formal training of public servants in degree and non-degree programs, giving the people charged with making public policy work for Canada the hands-on expertise to represent our vital interests both here and abroad;

- Improving Public Policy Discourse outside Government through executive and strategic assessment programs, building a stronger understanding of what makes public policy work for those outside of the public sector and helps everyday Canadians make informed decisions on the politics that will shape their futures;

- Providing a Global Perspective on Public Policy Research through international collaborations, education, and community outreach programs, bringing global best practices to bear on Canadian public policy, resulting in decisions that benefit all people for the long term, not a few people for the short term.

Our research is conducted to the highest standards of scholarship and objectivity. The decision to pursue research is made by a Research Committee chaired by the Research Director and made up of Area and Program Directors. All research is subject to blind peer-review and the final decision whether or not to publish is made by an independent Director.

\author{
The School of Public Policy \\ University of Calgary, Downtown Campus \\ 906 8th Avenue S.W., 5th Floor \\ Calgary, Alberta T2P $1 \mathrm{H} 9$ \\ Phone: 4032103802
}

\section{DISTRIBUTION}

Our publications are available online at www.policyschool.ca.

\section{DISCLAIMER}

The opinions expressed in these publications are the authors' alone and therefore do not necessarily reflect the opinions of the supporters, staff, or boards of The School of Public Policy.

\section{COPYRIGHT}

Copyright (C) 2017 by The School of Public Policy.

All rights reserved. No part of this publication may be reproduced in any manner whatsoever without written permission except in the case of brief passages quoted in critical articles and reviews.

\section{DATE OF ISSUE \\ March 2017}

\section{MEDIA INQUIRIES AND INFORMATION}

For media inquiries, please contact Morten Paulsen at 403-220-2540. Our web site, www.policyschool.ca, contains more information about The School's events, publications, and staff.

\section{DEVELOPMENT}

For information about contributing to The School of Public Policy, please contact Paul Beaudry by telephone at 403-220-4624 or by e-mail at paul.beaudry1@ucalgary.ca.

\section{ISSN}

1919-112x SPP Research Papers (Print)

1919-1138 SPP Research Papers (Online) 


\title{
RECENT PUBLICATIONS BY THE SCHOOL OF PUBLIC POLICY
}

\author{
POLICY RESPONSIVENESS AND POLITICAL ACCOUNTABILITY IN CITY POLITICS \\ http://www.policyschool.ca/wp-content/uploads/2017/03/Policy-Responsiveness-Sayers-Lucas.pdf \\ Anthony Sayers and Jack Lucas | March 2017
}

\section{0,000 INACTIVE OIL WELLS: A BLESSING OR A CURSE?}

http://www.policyschool.ca/wp-content/uploads/2017/02/Inactive-Oil-Wells-Muehlenbachs-1.pdf Lucija Muehlenbachs | February 2017

DISCERNING 'FUNCTIONAL AND ABSOLUTE ZERO': DEFINING AND MEASURING AN END TO HOMELESSNESS IN CANADA

http://www.policyschool.ca/wp-content/uploads/2017/01/Absolute-Zero-Turner-Albanese-Pakeman.pdf Alina Turner, Tom Albanese and Kyle Pakeman | January 2017

\section{PUBLIC-INTEREST BENEFIT EVALUATION OF PARTIAL-UPGRADING TECHNOLOGY}

http://www.policyschool.ca/wp-content/uploads/2017/01/PIB-Evaluation-Fellows-Mansell-Schlenker-Winter.pdf

G. Kent Fellows, Robert Mansell, Ronald Schlenker and Jennifer Winter | January 2017

MUNICIPAL REVENUE GENERATION AND SPRAWL: IMPLICATIONS FOR THE CALGARY AND EDMONTON METROPOLITAN REGIONS DERIVED FROM AN EXTENSION OF "CAUSES OF SPRAWL" (TECHNICAL PAPER)

http://www.policyschool.ca/wp-content/uploads/2016/12/MRG-Technical-Paper-McMillan.pdf Melville McMillan | December 2016

MUNICIPAL REVENUE GENERATION AND DEVELOPMENT IN THE CALGARY AND EDMONTON METROPOLITAN REGIONS http://www.policyschool.ca/wp-content/uploads/2016/12/MRG-Development-Conger-Dahlby-McMillan.pdf Brian Conger, Bev Dahlby and Melville McMillan | December 2016

THE CORPORATE INCOME TAX IN CANADA: DOES ITS PAST FORETELL ITS FUTURE? 2015 TAX-COMPETITIVENESS REPORT: CANADA IS LOSING ITS ATTRACTIVENESS

http://www.policyschool.ca/wp-content/uploads/2016/12/Corporate-Income-Tax-Bird-Wilson.pdf Richard Bird and Thomas Wilson | December 2016

http://www.policyschool.ca/wp-content/uploads/2016/11/Tax-Competitiveness-Bazel-Mintz.pdf Philip Bazel and Jack Mintz | November 2016

IF IT MATTERS, MEASURE IT: UNPACKING DIVERSIFICATION IN CANADA

http://www.policyschool.ca/wp-content/uploads/2016/11/Diversification-in-Canada-Tombe-Mansell.pdf Trevor Tombe and Robert Mansell | November 2016

\section{ALBERTA'S NEW ROYALTY REGIME IS A STEP TOWARDS COMPETITIVENESS: A 2016 UPDATE}

http://www.policyschool.ca/wp-content/uploads/2016/10/AB-New-Royalty-Regime-Crisan-Mintz-final.pdf Daria Crisan and Jack Mintz | October 2016

A RULE OF REASON FOR INWARD FDI: INTEGRATING CANADIAN FOREIGN INVESTMENT REVIEW AND COMPETITION POLICY http://www.policyschool.ca/wp-content/uploads/2016/10/Foreign-Investment-Bishop-Final.pdf Grant Bishop | October 2016

FROM IMPACT ASSESSMENT TO THE POLICY CYCLE: DRAWING LESSONS FROM THE EU'S BETTER-REGULATION AGENDA http://www.policyschool.ca/wp-content/uploads/2016/10/Financial-Regulation-Renda.pdf Andrea Renda | October 2016 